\title{
ТЕМНІ РЕГІСТРИ ПОТУШНЯКОВОГО СЛОВА
}

\author{
Папіш В. А.
}

\section{ВСТУП}

Зв'язок мови і психіки, кодування і декодування у слові прихованих імпульсів - ці питання знову актуалізуються сучасною психолінгвістикою. Розв'язання їх можливе після поглибленого занурення в художній текст і звернення до відповідних психологічних праць. Кінцевий результат тут передбачити складно, бо самість у кожного митця своя. У Федора Потушняка (1910-1960рр.) вона має темні регістри, що може бути зумовлено прихованою психологічною акцентуацією. Основна гіпотеза дослідження: у мові творів $\Phi$. Потушняка закодована епілептоїдна психологічна акцентуація. Довести це можна шляхом виокремлення з текстів і аналізу певних мовних патернів із психологічним змістом. У своїй статті використовуємо концептуальні ідеї німецького лікаря К. Леонгарда, якому належить грунтовне вчення про акцентуацію, та російського психолога й лінгвіста В. Бєляніна, який запропонував свою методику розшифрування психології автора в художньому тексті. Послуговуємося також термінологічною базою із психології та психіатрії (епілептоїдність, епілептоїд, акцентуація, акцентуант, акцентуйований). К. Леонгард розглядає акцентуацію характеру як посилення міри певних рис вдачі та характеру. Від психопатій акцентуація відрізняється тим, що відсутня однозначна визначеність їхнього прояву в усіх без винятку ситуаціях взаємодії людини зі світом: поведінка людини залишається варіабельною ${ }^{1}$. Акцентуація може бути закодованою в художньому мовленні. В. Бєлянін виділяє «світлі», «активні», «темні», «веселі», «сумні» та «красиві» тексти. Кожному виду відповідає певний тип акцентуації характеру особистості. «Світлі» й «активні» тексти свідчать про закодовану паранойяльність, «темні» про епілептоїдність, «веселі» - про маніакальність, «сумні» - про депресивність, «красиві» - про істероїдність ${ }^{2}$. Нині проблему

1 Леонгард К. Акцентуированные личности. Ростов-на-Дону : Феникс, 2000. URL: https://lib.uni-dubna.ru/search/files/psy_leongard/1.pdf.

${ }^{2}$ Белянин В. Основы психолингвистической диагностики (Модели мира в литературе). Москва : Тривола, 2000. URL: http://www.pedlib.ru/Books/3/ 0476/3_0476-259.shtml. 
акцентуації активно досліджують психологи, педагоги, медики, мовознавці. У лінгвістиці вона стала об'єктом вивчення в наукових працях В. Бєляніна ${ }^{3}$, Є. Чалкової ${ }^{4}$, Т. Прокоф’євої5, I. Мазирки ${ }^{6}$, Я. Бондаренко ${ }^{7}$, Т. Інкіної ${ }^{8}$ Названі автори проводять свої дослідження на матеріалі зарубіжної літератури. Ми ж спрямовуємо свою увагу на українську художню прозу. Вибір наш не випадковий. Ф. Потушняк (1910-1960 рр.) належить до знакових особистостей закарпатської школи української новелістики. Жив у непростий час, коли Закарпаття входило до Австро-Угорщини (до 1918 р.), Чехословаччини (19191938 рр.), гортистської Угорщини (1939-1944рр.), радянської України (3 1945 р). На території краю до 1945 р. не було єдиного правопису, стабільного підручника, твори видавалися так званим «язичієм», не всі закарпатці навіть усвідомлювали себе українцями. Ф. Потушняк педагог, археолог, етнограф, філософ, мовознавець, поліглот, письменник - відкрив землякам європейські наукові обшири, благотворно впливав на формування мовної культури читачів у діалектному оточенні, несучи до них естетично досконале слово. У радянський час, однак, був розкритикований за символізм, містику, ідеалістичний світогляд. Нині Ф. Потушняка активно видають, досліджують, вшановують і ставлять в один ряд із В. Стефаником, М. Черемшиною, Г. Хоткевичем, М. Коцюбинським. Життєтворчий шлях закарпатського інтелектуала по-новому осмислили літературознавці Є. Недзельський ${ }^{9}$ В. Микитась ${ }^{10}$, В. Поп ${ }^{11}$,

${ }^{3}$ Там само.

${ }^{4}$ Чалкова Е., Лапкина Т. Лингвистические и психолого-педагогические аспекты исследования акцентуаций личности. Москва : Народный учитель, 2001.

5 Прокофьева Т. Семантическое поле истероидной акцентуации личности : автореф. дис. ... канд. филол. наук. Москва, 2009.

6 Мазирка И. Психолингвистические основы вербальной характеристики личности и языковой картины мира героев художественной литературы : автореф. дис... докт. филол. наук. Москва, 2008.

${ }^{7}$ Бондаренко Я. Дискурс акцентуйованих мовних особистостей: комунікативнокогнітивний аспект (на матеріалі персонажного мовлення в сучасній американській художній прозі) : автореф. дис. ... канд. філол. наук. Київ, 2002.

${ }^{8}$ Инкина Т. Фразеосемантическое поле эпилептоидной акцентуации личности : автореф. дис. ... канд. филол. наук. Москва, 2005.

${ }_{9}$ Недзельский Е. Критические заметки о творчестве Ф. Потушняка. Русское слово. 1942. № № 42-47. С. 7.

10 Микитась В. Ф.М. Потушняк : літературно-критичний нарис. Ужгород : Закарпат. обл. кн.-газ. вид-во, 1961. 95 с.

11 Поп В. Побачений талантом світ. Честь роду : оповідання, повість, поезії y прозі / Ф. Потушняк. Ужгород : Карпати, 1973.С. 233-246. 
Л. Голомб $\sigma^{12}$, М. Козак ${ }^{13}$, В. Барчан ${ }^{14}$, О. Щербей ${ }^{15}$, Т. Лях ${ }^{16}$, мовознавці В. Статєєва ${ }^{17}$, М. Капраль ${ }^{18}$, Л. Бабота ${ }^{19}$, В. Папіш ${ }^{20}$. Попри велику кількість наукових розвідок, мовно-психологічна значущість його творів залишається маловивченою.

Mema cmammi - декодувати художне мовлення Ф. Потушняка для виявлення акцентуйованих рис і встановлення виду психологічної акцентуації. Саме в цьому полягає новизна нашої роботи, оскільки цей аспект текстів Ф. Потушняка ще не став предметом окремої наукової розвідки.

Об'єкт вивчення - лексичний тезаурус, синтаксичні одиниці, пунктуаційні риси, які репрезентують приховану акцентуйованість.

Актуальність пошуку зумовлена доцільністю системного опису мовних фактів, що вписується в контекст сучасної когнітивної

12 Голомб Л. Поетична творчість Федора Потушняка. Ужгород : Гражда, $2001.98 \mathrm{c}$.

${ }^{13}$ Козак М. Свосрідність ранніх поетичних збірок Ф. Потушняка. Молодь Украӥні : наукові записки молодих учених Ужгородського державного університету. Ужгород, 1995. Т. 5-6. С. 226-234.

${ }^{14}$ Барчан В. Повість Ф. Потушняка «Совість» : аспекти індивідуального стилю. Науковий вісник Ужгородського університету. Серія «Філологія. Соціальні комунікації». 2011. Вип. 25. С. 96-100. URL: http://nbuv.gov.ua/UJRN/Nvuufilol-2011-25-19.

15 Щербей О. Екзистенційно-онтологічна проблематика поезій у прозі Ф. Потушняка («Вікно», «Глибина», «Камені»). Сучасні проблеми мовознавства та літературознавства. 2013. Вип. 18. С. 138-140. URL: http://nbuv.gov.ua/UJRN/ spml-2013-18-26.

16 Лях Т. Метафізика пошуку в новелах Федора Потушняка. Слово $і$ час. 2019. № 1. C. 52-59.

${ }^{17}$ Статєєва В. Федір Потушняк - дослідник граматики Михайла Лучкая. Сучасні проблеми мовознавства та літературознавства. 2010. Вип. 14. С. 107-119. URL: http://nbuv.gov.ua/UJRN/spml-2010-14-19.

${ }^{18}$ Капраль М. Періодика Підкарпатської території 1939-1944 pp. (матеріали до повної бібліографії Федора Потушняка). Науковий $і$ мистеиький світ Федора Потушняка : матеріали Міжнародної наукової конференції, присвяченої 100-річчю від дня народження видатного українського письменника і вченого. Ужгород, 15-16 квітня 2010 р. С. 143-160.

${ }^{19}$ Бабота Л. Доробок Федора Потушняка в часописі «Літературна Неділя» та в журналі «Зоря-Наjnal”. Науковий $і$ мистецький світ Федора Потушняка : матеріали Міжнародної наукової конференції, присвяченої 100-річчю від дня народження видатного українського письменника і вченого. Ужгород, 15-16 квітня 2010 р. С. $120-129$.

${ }^{20}$ Папіш В. Лінгвокультурологічний та етнопсихологічний аспекти художньої прози Ф. Потушняка. Науковий вісник Ужгородського університету. Серія «Філологія. Соціальні комунікаиіï». Ужгород : видавництво УжНУ «Говерла», 2011. Вип. 26. С. 195-198. 
лінгвістики, та необхідністю доповнити наукову інтерпретацію індивідуального стилю талановитого закарпатського письменника.

Матеріалом дослідження слугували 34 оповідання Ф. Потушняка зі збірки «Повінь» ${ }^{21}$, 3 яких виокремлено мовні факти із психологічним змістом. Хронологічні межі написання творів - 1938-1948 pp.

\section{1. Лексичний тезаурус акцентуйованого письма Ф. Потушняка}

Незгода 3 авторитетними поглядами радянських ідеологів могла стати травматичним досвідом, який активізував у Ф. Потушняка приховану акцентуйованість. I це знайшло фіксацію в мові. Як зазначає В. Бєлянін, «кожен мовний елемент визначений не лише лінгвістичними, але й психологічними закономірностями $<\ldots>$ Структури художнього тексту корелюють зі структурами акцентуйованої свідомості» 2 . Акцентуйовані особистості - люди особливі. Вони нестандартні, нелегко приживаються в соціумі. А сила вияву реакцій залежить від типу акцентуації. Погоджуємося 3 думкою Ц. Чжияня, який зазначав, що «аналіз особливого лінгвопсихічного лексикону $<\ldots>$ дозволяє реалізувати вивчення мовного портрета як особливої дослідницької практики» ${ }^{23}$ (переклад наш - В. П.).

Якби потрібно кількома словами представити прозу Ф. Потушняка в мовному аспекті, можна б використати для цього такі маркери: ЛЮТЬ, РАПТОВІСТЬ, СТРАХ, СМЕРТЬ. Нервові напруження єднають багатьох Потушнякових персонажів в один психологічний тип - i це, по суті, сам автор у момент творчого напруження. Як писала Т. Миронова, «не має значення, якій темі присвячений вибраний текст, оскільки авторську руку та діапазон авторських сил видно в кожному

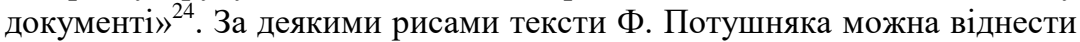
до «темних» (за В. Бєляніним). У таких текстах зазвичай описується

${ }^{21}$ Потушняк Ф. Повінь. Оповідання, новели, поезії в прозі, роман. Ужгород : Карпати, 1985. 576 с. (На це видання будемо покликатися під час цитування, зазначатимемо у круглих дужках назву твору й номер сторінки - В. П.).

22 Белянин В.П. Основы психолингвистической диагностики (Модели мира в литературе). Москва : Тривола, 2000. С. 5. URL: http://www.pedlib.ru/Books/3/0476/3_0476-259.shtml.

23 Чжиянь Ц. Модели речевого портрета и лингвопсихический портрет драматических персонажей в пьесе А.П. Чехова «Дядя Ваня». Историческая $u$ сочиально-образовательная мысль. 2016. № 8 (5/2). С. 192.

${ }^{24}$ Миронова Т. Незвичайні мовні явища в тексті особи, яка проголосила «смерть автора» (із досвіду комунікативно-когнітивного аналізу авторських якостей оригінального твору М. Фуко "Vivre avec la Philosophie"). Наукові записки Національного університету «Острозька академія». Серія «Філологічна». 2013. № 39. C. 183. 
важке життя людини у важких умовах. Моделювання художнього світу відбувається на всіх рівнях текстової системи, що містить загальну тональність прози, теми, заголовки, лексико-фразеологічні, синтаксично-інтонаційні, пунктуаційні засоби. В. Бєлянін пов'язує «темні» тексти 3 епілептоїдною психологічною акцентуацією, що пов’язана зі збудливістю, напруженістю й авторитарністю індивіда. «Людина з такою акцентуацією схильна до періодів злобно-тужливого настрою, роздратування з афективними вибухами, пошуку об'єктів для зняття злості. Дріб'язкова акуратність, скрупульозність, допитливе дотримання всіх правил, навіть на шкоду справі, допікають оточуючих, педантизм зазвичай розглядається як компенсація власної інертності. Вони не переносять непокори собі й матеріальних втрат» ${ }^{25}$. Свою агресію епілептоїди можуть контролювати. Також вони не мають почуття гумору (сміх нещирий, злорадний). Мовлення в них правильне, структуроване, зрозуміле всім. Вияв епілептоїдної акцентуації в системі мови дослідила T. Інкіна в кандидатській дисертації «Фразеосемантичне поле епілептоїдної акцентуації особистості» ${ }^{26}$. Серед позитивних рис епілептоїда дослідниця виділяє цілеспрямованість, твердість характеру, успіх, серед негативних озлобленість, гнів, жорстокість. Психолог А. Єгідес основні риси епілептоїдів представляє так (переклад з російської наш - В. П.): «Мова виразна. Мислення стандартне. Стриманий, але вибуховий. Любить порядок. Законник. Моралізатор. Скупий. Консерватор. Провідник ідеології. Інквізитор. Наводить справедливість. Надійний. Сім'янин» ${ }^{27}$. У К. Леонгарда для відповідного типу акцентуйованих осіб уживається інший термін - «збудливий»; основні риси: схильність до рукоприкладства, роздратованість; повільність мислення, незважаючи на інтелект, імпульсивність у поєднанні зі стриманістю 28.

На основі концепції В. Бєляніна коротко схарактеризуємо відповідний стиль художньої прози. Свою назву «темні» тексти мають через те, що зображувані події здебільшого відбуваються вночі, у місячному сяйві, сутінках, тумані. В описах часто йде дощ, сніг, персонажам холодно. Наявна також стилізація під просту, некультурну й неосвічену людину, звернення в основному до сільського життя.

25 Личко А. Психопатии и акцентуации характера у подростков. Ленинград : Медицина, 1983. С. 75.

${ }^{26}$ Инкина Т. Фразеосемантическое поле эпилептоидной акцентуации личности : автореф. дис. ... канд. филол. наук. Москва, 2005. 20 с.

27 Егидес А. Эпилептоид. Как разбираться в людях, или Психологический рисунок личности / А. Егидес. 2002. С. 4.

28 Леонгард К. Акцентуированные личности. Ростов-на-Дону: Феникс. 2000. URL: https://lib.uni-dubna.ru/search/files/psy_leongard/1.pdf. 
Лексика пов'язана з вестибулярним апаратом. Синтаксис свідчить про імпульсивність поведінки персонажів. Багато розділових знаків на початку і в кінці абзаців. Неприємні запахи і звуки. Головні персонажі мають якісь фізичні вади. Основними мотивами таких текстів є туга, злоба, страх, смерть. Дуже примітними є швидка зміна емоційного стану - від суму до люті. У «темних» текстах наявна опозиція: малий великий. Головний герой буває маленького зросту, а ворог великий. Негативні герої завжди повні, а позитивні - худі. Персонажі часто провалюються в колодязі, ями або просто несподівано падають (кореляція з епілепсією), або задихаються від нестачі повітря.

Низку вищевказаних ознак «темних» текстів ми виявили і у творах Ф. Потушняка. Розглянемо їх детальніше.

Виразно трагічні мотиви видно вже з окремих заголовків: «Смерть Петрика», «Крадіж», «Голод», «Злодій», «Чужі люди, «Невдача», «Жаль», «Позаздрив», «Шибениця», «Заздрість». В інших новелах трагізм концентрується не в заголовках, а у змісті. Наскрізною психологічною лінією творів $є$ тема смерті. Із 34-ох новел 30 звучить як реквієм. Помирають, наприклад, хворий Петрик (новела «Смерть Петрика»), старий Іван («Друзі»), дяк Поприк, якого зловили на крадіжці («Крадіж»); Іван Буряк, якого помилково звинуватили у злочині («Пригода»). Двірник Герман замерз на холоді під час полювання («Лови»). Убивають бабу в оповіданні «Гроші». Задушив багатьох односельців «упир» (Іван Чорник), а потім і сам загинув («Американтош»). Від голодної смерті вимерла ціла сім'я із шести людей («Голод»). Ховає хворого сина батько («Жаль»). Родичі вбивають, а потім спалюють в печі молоду дівчину, щоб заволодіти іiі спадком («Маланка»). Лісник («У лісі») не став рятувати побитого хлопця, якого розбійники вкинули в яму, а вранці із жахом упізнав у мертвому свого єдиного сина. Навіть якщо в новелі нікого не вбивають, то персонажі можуть згадувати про своїх померлих предків, оминають цвинтарі, роздумують про неможливе уникнення загибелі. На мовному рівні тема смерті фіксується відповідними лексикофразеологічними засобами, подаємо в мініконтекстах (усі виділення в цитатах наші - В. П.): хворий < ..> лежить на смерній постелі. В хаті чекають <..> його смерті («Друзі», с. 51); [баба Петрика] місящь тому померла («Смерть Петрика», с. 18); [баба - за козеням] залилася слізьми як за померлим. А за мерцем, своїм чоловіком, йй не доводилося так плакати, бо він був дуже старим («Коза», с. 28); малою дівчиною бачила свою мертву маму. <..> Шутя теж іде на смерть («Коза», с. 30); коли $6<\ldots>$ довелося руки скласти, «померти» («Смерть Петрика», с. 18). Умираючий ніби щзось жує <...> («Друзі», с. 52). Вікна - мертві, здивовані («Жаль», с. 76). Ания померла місяџь тому. 
Уже тиждень, як поховали Петрика й Анночку <..> Вона ще була на иих похоронах («Голод», с. 63). На третій день він так $і$ помер <...> («Пригода», с. 67); <..> як зернина у мертвому трунті («Шибениця», c. 145). В епілептоїдів смерть інколи настає раптово, люди падають, їм не вистачає повітря. Персонажі Ф. Потушняка помирають так само: $<\ldots>$ малі груденята важко віддихують, наче його щцось душить, спирає повітря («Смерть Петрика», с. 17). Петрик <... починає раптом важжко дихати. Витягується, в його грудях щесь стукає. Голівка падає назад, очі заходять білками («Смерть Петрика», с. 20). 3 ним діється щось незвичайне <...> Груди його перестають вбирати повітря <...> Він хоче закричати, але не може <...> i падає на долівку («Крадіж», с. 25). У новелах можна навіть виокремити «цвинтарну» мікротему, що зафіксовано в контекстах: <..> на цвинтарі лишився він сам. Хоче, видно, замкнути цвинтар. Починає рахувати: - За труну - 500 корун, за похорони - 100, за катафалк - 190, за чорне полотно - 50, дорога - $20<\ldots>$ Тисяча корун! < ..> O горе, горе! («Жаль», с. 77). А нині, коли йшла з цвинтаря $і$ иілувала хрест при дорозі, він засміявся < ..> («Чудо», с. 78).

Як уже зазначалося вище, необхідним атрибутом «темних» текстів $\epsilon$ номінації темноти. У Ф. Потушняка вона фіксується такими лексемами: темний, чорний, вечірній, тіні, ніч, місяиь, сутінки, сумерки, смеркатися, зірки, північ, темрява. Простежимо в контекстах: Темна пащека ночі («Смерть Петрика», с. 17); В хату закрадаються вечірні сутінки («Друзі», с. 53); В хату вбігають на довгих ногах вечірні сутінки («Друзі», с. 53); <..> спустилася сумовита ніч. Було дуже темно («Мати», с. 48); Вночі його непокоїв місяць <...> («Мати», с. 50); Ніч зоряна, але темна («Гроші», с. 45); Сумерки крадькома вилізли з глухого гілля і нагадували, що вечір близько <..> («Лови», с. 33); Наближався вечір. Ставало холодно («Лови», с. 34); 3 гущавини більше й більше наближалася ніч, чорною пеленою падала в нетрі і яруги, наповнюючи їх густими тінями <...>. Нарешті смеркалось («Лови», с. 34); Над лісом, з-за гірки, виповз місяць <...>. Він залив червоним світлом верхів'я лісу, що чорним морем хвилювалося між білими вериками гір («Лови», с. 36). Це чорне море <...> билося об скелі [про ліс вночі]; Десь далеко, <...> в кіниі того чорного моря, холодному місячному сяйві блищали вежі замку («Лови», с. 37); Чисте синє небо засяяло зірками. Інколи чують його [упиря] голос, коли темною ніччю нового місяия йде вздовж річки $<. .>$. Може, то їхній крик деколи чули ночами? Та хто може знати, якщо село завмирає уночі, охоплене страхом? («Американтош», с. 55). Місяць великим колесом вийшов над двором <...> («Стара Юлча», с. 72). Глянула на темне небо <...> («Чудо», с. 82). Крізь дерева пробивалися зірки на темному небі, заглядав місяць (Американтош», с. 98). Місяць 
ще висів над лісом < .. > («У лісі», с. 99). Ніч темна («Маланка», с. 91). Виявлено також описову форму зі вказівкою на пізній час: Встав з ліжка $<\ldots>$ На годиннику - 12. До ранку ще далеко («Гроші», с. 45). Місяць великим колесом вийшов над двором < ..> («Стара Юлча», с. 72); Темна вода в кринииі була спокійна! <..> Бабине лище від голоду подібне до чорної землі («Чудо», с. 78); Впала на коліна $і$ глянула в темну, як ніч, воду («Чудо», с. 79); Неба застелилося чорними хмарами. Глянула на темне небо, з якого лився животворний дощ («Чудо», с. 82); Батіг засвистів $\boldsymbol{i}$ чорною гадюкою упав йому на плечі («Чудо», с. 84); Чорні розбурхані хмари виступали з-за гір, готові застелити все небо («Чужі люди», с. 110); Русальна північ <..> темрява стає ще густіша («Верба», с. 112); Темна ніч все обмотала холодим, вогкістю й пусткою («Верба», с. 113); Свіжа весняна ніч. Небо усіяне зірками («В долині синьої ріки», с. 155). Лексема «темний» може бути атрибутом житлового чи навколишнього простору: Жінка Івана < ..> дивиться в темряву хати («Друзі», с. 54); Квартиру мав під дахом у будинку найтемнішої вулиці («Мати», с. 47); Хто знає, скількох з подорожніх скинув упир у ті прірви та темні ями. Чорними ночами виходив він з темних забутих печер $<\ldots>$ («Американтош», с. 55).

«Темні» тексти часто стилізують під село, як робить це i Ф. Потушняк. І представлено це не так на рівні культурних знань, як на рівні психологічного «проживання» непростого сільського життя. Нагадаємо, що сам Ф. Потушняк - людина енциклопедичних знань, поліглот, навчався на філософському факультеті Карлового університету у Празі, працював в Ужгородському університеті. Йому були б під силу найскладніші теми, філософські мотиви й незвичайні образи. Однак для новел він в основному обирає звичайну, буденну старовину. I це аж ніяк не сільська романтика, радше соціальнопсихологічне «дно», чорна нужда змучених людей. Як заспів до сумної пісні про селянське горе звучить уривок: Над селом - чорний морок, мов і не морок це, а довгий труд голодних, змучених людей. Мов це чорна, як земля, народна нужда, щцо дише з усіх закутків села, а воно покірно мовчить $\boldsymbol{i}$ чекає <...> («Сила життя», с. 126). Посилюють негативну експресію описи бідного, нелокалізованого села: Село бідне, загубилося серед гір і лісів, далеко від світу. А в інших селах своє лихо $<\ldots>$. Кожний бойться голоду й ховає все, щчо має <...> («Голод», c. 61). Наратора-епілептоїда «видає» також відтворення неприємного запаху, наприклад: Пара з горшків на грубиі заповнювала кімнату, смердюча, давня, як у хатах, де варять, сплять і живуть («Лови», c. 31); Хатина наповнена димом i чадом <...> («Друзі», с. 51); У повітрі пливли пахощі сухого бадилиння < ..> («Мати», с. 49); < ..> їхня хата <..> була дуже стара, запала, низька, покрита високою 
чорною стріхою («Брати», с. 114); [Будинок] наповнений таємничим підвальним запахом, властивим усім старим будинкам («Вогник», с. 101); Пахне гносм. Пасма павутиння звисають з поду $i$, здається, оживають у блідому світлі («Стара Юлча», с. 69).

- Що у вас такий запах у кухні? Як би щось гниле <...>, - говорить сусідка й морщить ніс.

Петро й Настя тільки тепер помічають, щэо розноситься виразний зanax mpyna.

- Мамо, з печі так погано воняе, - говорить мала Марійка. - Фу! («Маланка, с. 93).

Персонажами темних текстів $є$ представники простого народу. У Ф. Потушняка це - двірник, свинар, швець, лісник, жебрак, селяни, сторож, заробітчани. Усі вони важко працюють, живуть бідно й опиняються в обставинах, які не можуть перемогти, тому часто гинуть або втрачають глузд. Кульмінацією психологічного «сільського» контексту є вразлива залежність особи від соціуму. Так, у новелі «Крадіж» сільський дяк, рятуючи голодних дітей, зважився на злочин: пішов уночі красти кукурудзу. Його зловили. Ось як чоловік уявляє можливу реакцію села: Село здавалося йому тепер великим морем, щзо гуділо страшною вісткою про його нічний гріх. Той шум був немилосердним, лютим < ..> Цей шум розливається, обдає його холодними хвилями, а голова від цього стас гарячою, тіло слабким $i$ немічним («Крадіж», с. 24). А ще важче стає йому, коли уявляє свій похорон: Лиця у них [попа й криласників] насмішкуваті, скривлені. Коли вони піднімають голос, кутки уст у них також сміються <...> І голос їх теж насмішкуватий <...> Мов не похорони, а комедія <...> («Крадіж», с. 24-25). Від самої думки про можливий сором дякзлодій помирає. Персонаж новели «Маланка» уявляє собі, як би відреагувало село на відібраний у сироти спадок: Віддай сирітське! кричить щцсь йому у вухах, як удар молотком. I він бачить себе серед громади убогим, біднм, придавленим людськими очима < ..> («Маланка», с. 87). Щоб упередити таку ганьбу, чоловік убиває дівчину.

У Потушнякових новелах, як це характерно для «темних» текстів, головний персонаж обов'язково некрасивий - зазвичай блідий, худий, старий, 3 рудим або сивим волоссям. Наприклад, двірника Германа в дитинстві діти дражнили <..> за червоне волосся («Лови», с. 30), а його жінка - «бліда, в брудному фартусі («Лови», с. 32); жінка Працина жовта, суха, лице - як у мерця, лежить, мов колода, звалена непогодою. Обличчя - видовжене, худе, нерухоме («Голод», с. 61); довгий сухий юнак з дуже блідим лищем («Жаль», с. 75); батько хворого хлопчика Іван згорбився $\check{u}$ постарів <..> аж змарнів 
(«Смерть Петрика», с. 17); стара мати в сірому петеці виглядала маленькою, кривою, як тінь («Мати», с. 49); Батько був білий, як полотно («Гроші», с. 44). Ось портрет батьків хворого хлопчика в родині селян: У батька теж спітніле обличчя. Розкуйовджене волосся кучмою стирчить над низвким чолом. <... Мати вже й не плаче. Лиш лице їі видовжилося, ніс загострився («Верба», с. 110). Непривабливими $є$ й інші персонажі. Старий хихикає. У нього немає зубів, і лице від того здається викривленим («Брати», с. 116). [Дід Іван] < ..> старий та білий, як молоко < ..> Лице від старості поморщилося $i$ видовжилося («Шибениця», с. 146). Негативні персонажі, навпаки, красиві, молоді, повновидні: [граф] статний, ще молодий мужчина у високих рамлених чоботах («Лови», с. 31); Амбозій махнув полем, як молодий вітер («Чудо», с. 84); [Поросник, власник винниці] $A$ сам товстий, одягнений, з золотим ланцюжком на череві, а дочка - як пава < ..> («Гроші», с. 41); < ..> ж⿻андарм молоденький, красний, ще майже хлопчак < .. > («Невдача», с. 130).

Кодування авторських інтенцій може закріплюватися і спільною портретною рисою персонажів. Так, афективний стан можуть передавати гарячі, налиті кров'ю очі, що засвідчено в контекстах: [Петрик] дивиться кривавими оченятами на Івана («Смерть Петрика», с. 20); Марія - сухолиия, з кривавими підсліпуватими очима («Коза», с. 26); Коза глянула на бабу, <..> в очах показалася кров («Коза», с. 28); Колючі, вогняні очі [вовка] дивляться в обличчя («Лови», с. 38); Його очі стали червоні $і$ дивилися, не відриваючись, на руїни; Його очі палали («Гроші», с. 47); <..> $>$ вогненними очима обличчя [Івана] («Друзі», с. 51); <..> хворому стає легше, $i$ він водить гарячими очима по кімнаті <..> («Друзі», с. 51); [Упир] високий, міиний, страшний, зарослий, з вогняними очима («Американтош», с. 55); [Іван Чорник] похмурий, злий. Очі - пекучі («Американтош», с. 57); Тяжко дихав, кров била у вічі («Позаздрив», с. 135). «Гаряче» портретування загострених афективних станів доповнюють часті описи гніву, страху або гарячки: кров у жилах аж кипить («Гроші», с. 46); лице горіло полум'ям («Крадіж», с. 24); Все тремтить перед ним у вогняних барвах [людина замерзає на морозі] («Лови», с. 38); $\boldsymbol{C m p a x ~}<\ldots>$ горів y ньому, як запалена копиця сіна на вітрі («Крадіж», с. 22-23); він уже не чув ні свого серия, ні свого гарячого подиху («Крадіж», с. 24); Дома взяла його страшна гарячка <..> («Пригода», с. 67); Гарячі, щирі сльози течуть по ї̈ обличчю <..> («Чудо», с. 78); аж піт покотився з розгарячених облич («Чудо», с. 80); Мене спалив гнів («Невдача», с. 128); Кров била у скроні («Позаздрив», с. 135); Раптом гаряча сльоза покотилася мені по лиџю з болю («Шибениця», с. 145). 
Отже, лексичних та стилістичних ознак «темних» текстів у мовотворчості Ф. Потушняка представлено немало. Гіпотетично можна припустити, що творчість могла стати для письменника тим компенсаторним механізмом, що забезпечив психічне здоров'я особистості. Колись Леся Українка в листі до I. Франка писала: «<...> моя Одержима розбила голову слузі синедріону, так зате у всіх моїх знайомих голови і досі цілі $<\ldots>$. ${ }^{29}$.

\section{2. Пунктуаційні та синтаксичні засоби акцентуйованого письма Ф. Потушняка}

Збільшує обсяг інформації про автора акцентуйована пунктуація та синтаксичні особливості речень, що об'єктивуються надмірним використанням розділових знаків на початку і в кінці абзаців, чіткою побудовою фраз. Зокрема, новели рясніють трьома крапками й тире. Трапляються й поєднання знака оклику й крапок. У традиційній пунктуації трьома крапками позначають обірвані речення або пропуски в текстах. Щоб не сплутати авторські знаки й наші пропуски в цитатах, місця пропусків ми позначаємо трьома крапками в кутових дужках. Крім графічних знаків, впадає в око добре структурований текст із великою кількістю абзаців, коротких речень. Наведемо кілька прикладів зі збереженням авторських абзаців:

Схилив голову і думає про свої важкі думки ... А за думками вирує те, щзо має прийти, невидиме, холодне, страшне. Він знає: воно прийде, але намагається його заперечити - не вірити собі <..> («Смерть Петрика», с. 17).

...3 голосу тої сопілки перед їх очима виростала рідна хата з широкими лавами, дубовим столом. За тим столом сидить господар хати. Гора, не чоловік!.. Богатир, опришок, якого радо всі слухають, шанують ... Знають, він нападає зі своїми друзями на багатих лихварів та злих панів ... Одначе ніхто з села проти цього не виступає, бо знають, щзо він добре робить робить, як йому придано («Прадідівська», с. 146).

...Залишився після богатиря маленький синок. У багатьох служив - битий, зневажуваний, у голоді та холоді ріс. Та не пропав виріс («Прадідівська», с. 147).

...Неділя. Люди вийшли з иеркві по службі. Поставали собі, як звичайно («Американтош», с. 59).

29 Українка Леся. Зібрання творів : у 12-ти т. Київ : Наукова думка, 1977. T. 12. C. 18. 
М'ясо спеклося... Управляючий витяг рюкзак і вийняв звідти пляшки й хліб... Граф < ..> покликав Германа і подав йому найбільший шматок дичини хлібом і одну пляшку ... («Лови», с. 35)

Зловживання трьома крапками підсилює модель творення афективних емоцій, хвилювання, зворушення. Цим знаком не тільки закінчуються абзаци, але часто й починаються; ним також можуть розриватися речення. Можливо, авторові не вистачало повітря від хвилювання у хвилину творчого напруження. Три крапки в такому разі передають не до кінця виражену думку. Чітке структурування тексту й розділові знаки свідчать про різкість, відривчастість, що притаманно епілептоїдам.

\section{ВИСНОВКИ}

Отже, мова - явище не тільки лінгвістичне, але й психологічне. У художньому мовленні $\Phi$. Потушняка зафіксовано результат підсвідомих психічних процесів, характерних для загострених станів творчої особистості. Основну гіпотезу дослідження - у мові творів Ф. Потушняка закодована епілептоїдна психологічна акцентуація вдалося довести шляхом виокремлення 3 текстів і аналізу мовних патернів із психологічним змістом. Виразно трагічні мотиви, могильні асоціації, похмура модель села, лексика на позначення смерті, неприємного запаху, темноти, портретування позитивних персонажів у непривабливому світлі, зловживання розділовими знаками, добре структуроване мовлення - усе це $\epsilon$ ознаками «темних» текстів, що пов'язуюся дослідниками із прихованою епілептоїдною акцентуацією. Проаналізовані нами текстові сегменти засвідчують те, що Ф. Потушняк прожив дуже напружене i важке життя, яке знайшло відбиття в мові. Соціальне оточення та тодішня політична система могли стати тим травматичним середовищем, що активізувало приховану акцентуйованість, а творчість відіграла терапевтичну роль, яка допомогла митцеві залишатися психологічно здоровим. Критичне оцінювання мовної мистецької творчості 3 використанням сучасних методик дає змогу виявити неусвідомлені автором пережиті емоції. Перспективу дослідження вбачаємо в розширенні дослідницької бази, виявленні мовних знаків закодованої епілептоїдності на матеріалі інших творів письменника. Процедура аналізу може бути екстрапольована й на художній доробок інших авторів.

\section{АНОТАЦІЯ}

Мета дослідження - декодувати художнє мовлення Ф. Потушняка для виявлення прихованої епілептоїдної акцентуації.

Стаття написана у психолінгвістичному плані і спрямована на аналіз прихованих психологічних рис у художньому мовленні. У статті 
прокоментовано явище психологічної акцентуації в лінгвістиці та психології, охарактеризовано психологічні складники «темних» текстів. На матеріалі новелістики відомого закарпатського митця Ф. Потушняка схарактеризовано мовні факти, які засвідчують приховану акцентуацію. Встановлено кореляційні зв'язки між лінгвістичними ознаками його текстів та психологічними параметрами наратора-акцентуанта.

Критичне оцінювання мовної мистецької творчості з використанням сучасних методик дає змогу виявити неусвідомлені автором пережиті емоції та приховані психологічні риси. Темні регістри Потушнякового мовлення спричинені прихованою епілептоїдною акцентуацією, що на рівні тексту втілилася у трагічних мотивах, стилізації під село, лексиці на позначення смерті, неприємного запаху, темноти, на портретуванні позитивних персонажів у непривабливому світлі, зловживанні розділовими знаками, добре структурованому мовленні. Соціальне оточення та тодішня політична система могли стати тим травматичним середовищем, що активізувало приховану акцентуйованість, а творчість відіграла терапевтичну роль, яка допомогла митцеві залишатися психологічно здоровим. Перспективу дослідження вбачаємо у виявленні мовних знаків закодованої епілептоїдності на матеріалі інших творів письменника.

\section{ЛIТЕРАТУРА}

1. Бабота Л. Доробок Федора Потушняка в часописі «Літературна Неділя» та в журналі «Зоря-Најnal”. Науковий $і$ мистещький світ Федора Потушняка : матеріали Міжнародної наукової конференції, присвяченої 100-річчю від дня народження видатного українського письменника і вченого. Ужгород, 15-16 квітня 2010 р. С. 120-129.

2. Барчан В. Повість Ф. Потушняка «Совість»: аспекти індивідуального стилю. Науковий вісник Ужгородського університету. Серія «Філологія. Соціальні комунікації». 2011. Вип. 25. С. 96-100. URL: http://nbuv.gov.ua/UJRN/Nvuufilol_2011_25_19

3. Белянин В. Основы психолингвистической диагностики (Модели мира в литературе). Москва : Тривола, 2000. URL: http://www.pedlib.ru/Books/3/0476/3_0476-259.shtml.

4. Бондаренко Я. Дискурс акцентуйованих мовних особистостей: комунікативно-когнітивний аспект (на матеріалі персонажного мовлення в сучасній американській художній прозі) : автореф. дис. ... канд. філол. наук. Київ, 2002.

5. Голомб Л. Поетична творчість Федора Потушняка. Ужгород : Гражда, 2001. $98 \mathrm{c}$. 
6. А. Эпилептоид. Как разбираться в людях, или Психологический рисунок личности / А. Егидес. 2002. URL: https://www.psychologos.ru/ articles/view/epileptoid-.

7. Инкина Т. Фразеосемантическое поле эпилептоидной акцентуации личности : автореф. дис. ... канд. филол. наук. Москва, 2005. $20 \mathrm{c}$.

8. Капраль М. Періодика Підкарпатської території 1939-1944 pp. (матеріали до повної бібліографії Федора Потушняка). Науковий імистецький світ Федора Потушняка : матеріали Міжнародної наукової конференції, присвяченої 100-річчю від дня народження видатного українського письменника і вченого. Ужгород, 15-16 квітня 2010 p. C. $143-160$.

9. Козак М. Своєрідність ранніх поетичних збірок Ф. Потушняка. Молодь - Україні : наукові записки молодих учених Ужгородського державного університету. 1995. Т. 5-6. С. 226-234.

10. Леонгард К. Акцентуированные личности. Ростов-на-Дону : Феникс. 2000. URL: https://lib.uni-dubna.ru/search/files/ psy_leongard/1.pdf.

11. Личко А. Психопатии и акцентуации характера у подростков. Ленинград : Медицина, 1983. URL: https://www.twirpx.com/file/14291/.

12. Лях Т. Метафізика пошуку в новелах Федора Потушняка. Слово $i$ чac. 2019. № 1. С. 52-59.

13. Мазирка И. Психолингвистические основы вербальной характеристики личности и языковой картины мира героев художественной литературы : автореф. дис... докт. филол. наук. Москва, 2008.

14. Микитась В. Ф.М. Потушняк : літературно-критичний нарис. Ужгород : Закарпат. обл. кн.-газ. вид-во, 1961. 95 с.

15. Миронова Т. Незвичайні мовні явища в тексті особи, яка проголосила «смерть автора» (із досвіду комунікативно-когнітивного аналізу авторських якостей оригінального твору М. Фуко "Vivre avec la Philosophie"). Наукові записки Національного університету «Острозька академія». Серія «Філологічна». 2013. № 39. С. 182-186. URL: http://nbuv.gov.ua/UJRN/Nznuoaf_2013_39_57

16. Недзельский Е. Критические заметки о творчестве Ф. Потушняка. Русское слово. 1942. № № 42-47. С. 7.

17. Папіш В. Лінгвокультурологічний та етнопсихологічний аспекти художньої прози Ф. Потушняка. Науковий вісник Ужгородського університету. Серія «Філологія. Соціальні комунікаиї̈. Ужгород : видавництво УжНУ «Говерла», 2011. Вип. 26. С. 195-198. 
18. Поп В. Побачений талантом світ. Честь роду : Оповідання, nовість, поезї в прозі / Ф. Потушняк. Ужгород : Карпати, 1973. C. 233-246.

19. Потушняк Ф. Повінь. Оповідання, новели, поезії в прозі, роман. Ужгород : Карпати, 1985.

20. Прокофьева Т.В. Семантическое поле истероидной акцентуации личности: автореф. дис. ... канд. филол. наук. Москва, 2009.

21. Статєєва В. Федір Потушняк - дослідник граматики Михайла Лучкая. Сучасні проблеми мовознавства та літературознавства. 2010. Вип. 14. С. 107-119. URL: http://nbuv.gov.ua/UJRN/spml_2010_14_19.

22. Українка Леся. Зібрання творів : у 12-ти т. Київ : Наукова думка, 1977. T. 12.

23. Чалкова E., Лапкина T. Лингвистические и психологопедагогические аспекты исследования акцентуаций личности. Москва : Народный учитель, 2001.

24. Чжиянь Ц. Модели речевого портрета и лингвопсихический портрет драматических персонажей в пьесе А.П. Чехова «Дядя Ваня». Историческая и соииально-образовательная мысль. 2016. № 8 (5/2). C. 190-194. DOI: 10.17748/2075-9908-2016-8-5/2-190-194.

25. Щербей O. 2013. Екзистенційно-онтологічна проблематика поезій у прозі Ф. Потушняка («Вікно», «Глибина», «Камені»). Сучасні проблеми мовознавства та літературознавства. 2013. Вип. 18. C. 138-140. URL: http://nbuv.gov.ua/UJRN/spml_2013_18_26.

\section{Information about the author:} Papish V. A., Candidate of Philology, Associate Professor at the Ukrainian Language Department Uzhhorod National University 46, Pidhirna str., Uzhhorod, 88000, Ukraine 